\title{
The Struggle of Integration: James Baldwin and Melanie Klein in the Context of Black Lives Matter
}

\author{
David W. McIvor Colorado State University
}

\begin{abstract}
Recent killings of unarmed black citizens are a fresh reminder of the troubled state of racial integration in the United States. At the same time, the unfolding Black Lives Matter protest movements and the responses by federal agencies each testify to a not insignificant capacity for addressing social pathologies surrounding the color line. In order to respond to this ambivalent situation, this article suggests a pairing between the work of James Baldwin and that of the psychoanalyst Melanie Klein. I will argue that we cannot fully appreciate the depths of what Baldwin called the "savage paradox" of race without the insights provided by Klein and object relations psychoanalysis. Conversely, Baldwin helps us to sound out the political significance of object relations approaches, including the work of Klein and those influenced by her such as Hanna Segal and Wilfred Bion. In conversation with the work of Baldwin, object relations theory can help to identify particular social settings and institutions that might allow concrete efforts toward racial justice to take root.
\end{abstract}

Keywords: psychoanalysis, integration, Black Lives Matter, Melanie Klein

If the word integration means anything, this is what it means: that we, with love, shall force our brothers to see themselves as they are, to cease fleeing from reality and begin to change it.

James Baldwin, The Fire Next Time $(1963)^{1}$

The killings in late 2014 and early 2015 of unarmed black citizens in Ferguson, MO, Staten Island, N.Y., Baltimore, MD, and Charleston, S.C.- and the national protests that followed from these killings-provided fresh evidence that the state of racial integration in the United States is still troubled, to put it mildly. The

James Baldwin Review, Volume 2, 2016 @ The Authors. Published by Manchester University Press and The University of Manchester Library 
killings, as protesters repeatedly insisted, were not simply tragedies in their own right but symptoms of a larger social condition of disregard, misrecognition, insecurity, and disrespect. In this context, the rallying cries of "black lives matter" did not represent a self-evident truth but a reminder that the opposite is still often the case-a clear-eyed acknowledgment of the ways in which black lives are still routinely devalued or disregarded. Within a prison system that Michelle Alexander refers to as the "new Jim Crow," more black bodies are incarcerated or on parole than were enslaved in $1850 .^{2}$ An African-American male born today in the state of California has a greater statistical likelihood of spending a day in jail than he does of spending a day in college. ${ }^{3}$ Significant racial inequalities in income, educational attainment, health, and life expectancy have remained stubbornly stable over the past several decades.

Despite these sobering indicators of obvious social maladies, it is also important to acknowledge that the Black Lives Matter protests in Ferguson, Baltimore, and elsewhere testify not only to increasing social awareness of these problems but to a not insignificant civic capacity for response. The reaction of the federal government to the killings in Ferguson and Staten Island was also notably different from the recent past. During civil rights agitation in the 1960s, Attorney General Robert Kennedy and FBI director J. Edgar Hoover authorized wiretaps of civil rights leadership, and Hoover was also famously responsible for sending a letter to Martin Luther King, Jr.--supposedly from a disillusioned civil rights advocateimploring the recipient to commit suicide. ${ }^{4}$ In the wake of the events in Ferguson, however, the Attorney General Eric Holder presided over a scathing Justice Department report that accused the local police department of racial discrimination and exploitation, which motivated the resignation of several public officials including the City Manager and Police Chief. In February of 2015, the director of the FBI, James Comey, gave an unprecedented public speech in which he called on police departments to confront conscious and unconscious racial biases. ${ }^{5}$ The same speech in the mouth of Hoover would have been simply unimaginable.

The overall picture, then, is one of neither unmitigated catastrophe nor undeniable progress but an ambivalent mixture of the two. The double-sided challenge for American citizens is therefore to prevent the narrative of progress from swallowing up the bitter realities of racial injustice, while also preventing discourses of social disaster from overwhelming our ability to discern markers and mechanisms of improvement. In order to respond to this ambivalent situation, this article will suggest a pairing between the work of James Baldwin and that of the psychoanalyst Melanie Klein. Baldwin may seem like an obvious candidate to theorize a vocabulary to respond to our contemporary racial politics, but his pairing with Klein might seem surprising. Klein showed little interest in questions of race or of social justice. Nevertheless, I will argue that we cannot fully appreciate the depths of what Baldwin called the "savage paradox" of race without the insights provided by Klein and object relations psychoanalysis. ${ }^{6}$ Conversely, Baldwin helps us to sound out the political significance of object relations approaches, including the work of Klein and those influenced by her such as Hanna Segal and Wilfred Bion. 
My argument, in brief, is this: Baldwin's work illuminates the ethical and political stakes of a Kleinian approach, because it repeatedly draws a connection between the struggle for racial justice and a struggle-both social and psychological-for what both Baldwin and Klein call integration. While Baldwin and Klein use the term "integration" in radically different situations-Baldwin's frame of reference is the Civil Rights movement of the mid-twentieth century, whereas Klein is reflecting on challenges of interpersonal development from within her analytic practice in Britain before and after the Second World War-there are some striking similarities between their approaches. Baldwin, for instance, repeatedly insisted that America's political destiny was linked with citizens' ability to "see themselves as they are" - to face down not only the ongoing legacies of white supremacy but to acknowledge and contain deep human needs, anxieties, and terrors. ${ }^{7}$ Klein's contributions to object relations theory help us to conceptualize not only the intransigent intrapersonal and interpersonal dynamics and defenses that spoil these insights; further, in conversation with the work of Baldwin, object relations theory can help to identify particular social settings and institutions that might allow concrete efforts toward racial justice to take root.

My argument is divided into three sections. First, I discuss and contextualize Baldwin's resistances to psychoanalysis. These resistances ultimately rest upon Baldwin's reductionist understanding of psychoanalysis as a process of "adjustment" and sexual normalization. Yet Baldwin's concepts and concernsinnocence, inheritance, ambivalence, integration, and the desire, anguish, terror, and pain within human life and within America's racial politics-resonate deeply with the object relations school of Klein, Segal, and Bion. In section II, I sound out these resonances, and in the final section I show how the work of Klein and Baldwin complement each other and mutually illuminate the pathologies and possibilities of our ambivalent racial present. There are conceptual resources in Klein and object relations that provide a means of engaging and understanding the savage paradoxes identified eloquently by Baldwin, and together this work points toward spaces and practices that might unwind some of the anxieties and fears swirling within contemporary America’s toxic racial environment. ${ }^{8}$

Baldwin repeatedly rejected an engagement with psychoanalysis. When asked by an interviewer if he had ever been in analysis, Baldwin responded vociferously: "God no, never got 'adjusted"' 9 This objection echoes other moments in Baldwin's writings where he disparages the psychoanalytic encounter and tradition. As he writes in Tell Me How Long the Train Has Been Gone, "I have always very keenly felt, in the psychiatric account, the absence of the two most important people, one of them being the psychiatrist and the other being me." ${ }^{10}$ Clearly, Baldwin did not feel an affinity with Sigmund Freud or with psychoanalytic approaches, and even in the moments where Baldwin seems to be referencing Freud-for instance the famous passage in "Many Thousands Gone" where Baldwin invokes the story of 
Oedipus and claims, "it is a sentimental error ... to believe that the past is dead"Baldwin refuses to make an explicit connection. ${ }^{11}$

Baldwin's leeriness toward psychoanalysis was likely overdetermined, but one obvious source of discomfort was psychoanalysis's historical attitude toward homosexuality as a pathological disorder rooted in narcissism, an inferiority complex, or similar personality deficiencies. It is worth recalling that the American Psychiatric Association only deleted homosexuality as a category of psychological pathology in 1973, a sad and sobering fact that one can hear reflected in Baldwin's dismissal of analysis as "adjustment." And while Freud's attitude toward homosexuality seemed to evolve, the general tendency to pathologize homosexuality within psychoanalysis, combined with the rigid sexual moralism of the United States in the mid-twentieth century, seemed to cement in Baldwin's mind an association between the two.

Despite his resistances to the vocabulary of psychoanalysis, however, this vocabulary is, I argue, a better fit for many of Baldwin's ideas than some of the other registers in which he wrote. For instance, the religious language of redemption, salvation, and of the sanctity of the "soul" is omnipresent in Baldwin's writings, and is in part attributable to his upbringing in the Pentecostal Church and his adolescent foray behind the pulpit. Baldwin repeatedly insisted on a connection between the larger social struggle for racial justice and a kind of soulcraft. As he put it in 1970, "I always felt that when I was talking publicly ... I was talking to people's souls; I was never really talking about simply political action."12 However, redemption for Baldwin is clearly a worldly endeavor; as George Shulman points out, Baldwin narrates redemption "not as an exodus from captivity but as a coming-to-terms with captivity's complex, haunting legacy."13 In other words, Baldwin trades upon the resonances of a religious-infused vocabulary while subverting the conventions and assumptions of that vocabulary. His use of the term "soul," for instance, seems to come closer to the Freudian notion of the psyche than the immortal Christian soul that might be "saved" or must be prepared for an afterlife. There are no intimations of a redemptive afterlife; instead Baldwin focuses on building psyches that can navigate the complexities and terrors of this world.

Relatedly, the reckoning with history that Baldwin repeatedly called for implicitly relies upon a theory of the unconscious mind. Baldwin insisted both that white Americans "know the crimes they have committed against black people" and that they do not know about these crimes. ${ }^{14}$ The apparent contradiction can be best explained by the idea that unconscious knowledge of white supremacy could not be consciously admitted or publicly acknowledged. As Baldwin put it in 1962, the "problem of American identity has everything to do with all the things that happened in this country but never have been admitted or dealt with." ${ }^{15}$ It is not the knowledge itself but the acceptance of the knowledge that is the problem, and addressing this problem involves what can best be described as affective and psychological transformation. Racial "innocence" is not ignorance-it is instead a kind of continual denial, a refusal to admit that which is already known.

The battle against racial innocence, therefore, involves not only the material or 
policy manifestations of white supremacy, or a battle against historical ignorance, but also a struggle against habits of denial. In this respect, the tactics used to reinforce status boundaries and racial innocence bear more than a superficial resemblance to psychological defenses. The struggle for racial justice has to exceed a struggle against unjust laws, segregated institutions, or even "racism." As Baldwin put it, "the battle is elsewhere. It proceeds far from us in the heat and horror and pain of life itself where all men are betrayed by greed and guilt and blood-lust and where no one's hands are clean." 16

Aside from his implicit account of a soul or psyche in process, an active unconscious, and the interconnection between racial injustice and psychological defenses, Baldwin's psychoanalytic assumptions are also revealed within his prescribed "cure" for racial innocence, which, as Lauren Rusk observes, is a "kind of self-administered psychoanalysis." 17 It is only by "acknowledging our destructive impulses and acts" that we can "outgrow them," and "the past will remain horrible for exactly as long as we refuse to assess it honestly." ${ }^{18}$ In other words, although Baldwin consciously rejected an engagement with psychoanalytic frameworks, he diagnosed American society in psychoanalytic terms of repression and denial, and he prescribed an affective-cognitive cure that resembles nothing so much as the work of analysis.

Yet this is not all. Baldwin's unconscious psychoanalytic register is perhaps most clear in his understanding of the craft of writing and the value of what he called "poets." The poet serves as a means by which individuals can digest the indigestible aspects of their existence, or wrest a kind of coherence from an incoherent reality. The poet or writer, according to Baldwin, does not simply reflect his or her own experience but provides witness to the pathologies and disasters of the world in ways that permit a somehow "truer" understanding of those disasters:

Billie Holiday was a poet. She gave you back your experience. She refined it, and you recognized it for the first time because she was in and out of it and she made it possible for you to bear it. And if you could bear it, then you could begin to change it. That's what a poet does. ${ }^{19}$

The poet or artist, according to another one of Baldwin's formulations, provides a "disagreeable mirror" that reflects back one's experiences in such a way as to compel recognition of the social and psychic disasters we do so much to deny. The idea of a disagreeable mirror is, as Shulman notes, a way for Baldwin to conceptualize "the war of an artist with his society" as "a lover's war." 20 The poet "does, at his best, what lovers do, which is to reveal the beloved to himself and, with that revelation, to make freedom real." ${ }^{21}$ The disagreeable mirror, which gives back and refines experiences in a way that overcomes unconscious defenses and myths of innocence, again resembles nothing so much as the psychoanalytic encounter.

To draw a connection between Baldwin and psychoanalysis is not, then, to provide a belated "adjustment" for Baldwin or to put Baldwin himself on the couch. Rather, it is to show how Baldwin's basic assumptions, categories, and ideas 
resonate deeply with psychoanalytic approaches. Baldwin therefore helps us see the interconnections between the vocations of the poet and the analyst by showing how the terrain of the analyst-the fractious desires and the complexity of the self-must be included in the self-understandings and labor of the poet. Baldwin seemed uninterested in using psychoanalysis in this way, but this should not stop us from both deploying psychoanalytic concepts to explain the interconnections between human anxieties, fears, desires, and historical practices of domination and exclusion, while also identifying social spaces and civic practices through which we might begin to unwind some of these pathologies. ${ }^{22}$

\section{II}

Psychoanalysis, of course, is a vast territory that encompasses a variety of conflicting approaches, assumptions, and vocabularies. Yet Baldwin's work most clearly resonates with the object relations approach inaugurated by Melanie Klein and developed by Hanna Segal, D. W. Winnicott, and Wilfred Bion. Klein initially trained under Sandor Ferenczi and Karl Abraham in Budapest and Vienna, respectively, in the 1920s, but shortly after Abraham's death she moved to London where she remained until her death in 1960. Klein's work gradually peeled away from the dynamic drive assumptions of orthodox Freudianism, which emphasized the necessary interrelationship between the drives and our relations with internal and external objects. The instincts, for Klein, are "ab initio indivisibly linked with object-relations." ${ }^{3}$ In other words, there are complex and ongoing interactions between a desiring, fantasy-producing subject and an environment replete with objects that bend, shape, contain, and modify those desires and fantasies. In comparison with Freud, then, Klein's work "sociologizes the individual" while maintaining that the individual is never a pale reflection of its environment but a source of fantasies, desires, and creative identifications in perpetual interaction with its environment. ${ }^{24}$ In the latter half of the twentieth century, Klein's analysands and successors, such as Segal and Bion, developed and extended the object relations approach, in part by analyzing the role that groups play in an individual's development. $^{25}$

Klein's most significant insights and conceptual innovations shed light on what Baldwin saw as the interconnected struggles or "battles" against both white supremacy and the "heat and horror and pain of life itself." ${ }^{26}$ In particular, I will focus below on three striking common points of emphasis across Baldwin and Klein. First is their common emphasis on the importance of early life, or the idea that primary experiences leave traces that linger far into maturity. Second is the relationship between race consciousness and what Klein called the "positions" of psychic functioning and the defense of "projective identification." 27 Third is Klein's and Baldwin's use of the term "integration," which Klein referred as the "ultimate aim of psychoanalysis." 28 For Klein, failures of integration occur when we project the discomforting parts of the self out into a persecutory other, and when we construct boundaries to police the fantasized separation. Once again, while Baldwin's 
writings on integration operated in a very different context and for very different purposes, he also saw integration partly in terms of an inner struggle to acknowledge "our common humanity ... by taking a hard look at oneself." ${ }^{29}$ Across their vast differences, then, Baldwin and Klein can be made to speak to one another and to us in ways that illuminate the difficulties and opportunities for a politics of integration amid ongoing incidents of racial violence and disrespect.

\section{Early life}

Klein's deviations from Freud were rooted in her analysis of young children, leading her to challenge Freud's assumptions about infantile narcissism. Klein argues that the infant is open to the world and experience from birth-if not before. Whereas Freud posited a pre-social struggle in the psyche between life and death instincts, Klein argued that it is the infant's utter dependency on its earliest objects that touches off a struggle between love and hatred-life and deaththat is then continually played out through the remainder of life. ${ }^{30}$ For Klein, the early self encounters an ambivalent world; it experiences moments of both care and deprivation, intense anxiety and reassuring comfort, and the ambivalence of early object relations calls forward destructive defenses and capacities such as greed, envy, and hatred. Klein traces this to the infant's earliest encounters with the caregiver, who, in providing satisfaction for the infant's wild, uncontrollable needs helps the infant develop a coherent internal structure to hold those experiences. Alongside these experiences of care, however, are unavoidable experiences of deprivation. While these latter experiences can ultimately be integrated and their effects mitigated, they nevertheless leave their mark, establishing a tension between love-manifested through reciprocal acts of recognition-and hatredmanifested by conscious and unconscious attacks on the other-that resembles Freud's remark about the "battle of the giants that our nursemaids try to appease with their lullaby about heaven." ${ }^{1}$

Baldwin, in similar fashion, emphasizes the inescapable impact of early experiences, which leave behind an ambivalent inheritance that must be faced down and integrated into the self. As he put it, "nobody ever recovers, really, from his earliest impressions." ${ }^{32}$ In another interview he argued, "no one really ever gets over his beginnings," an idea that strikes at the heart of innocence narratives of rebirth or overcoming. ${ }^{33}$ Perhaps the most eloquent statement of this idea, however, is in "Many Thousands Gone":

It is a sentimental error ... to believe that the past is dead; it means nothing to say that it is all forgotten, that the Negro himself has forgotten it. It is not a question of memory. Oedipus did not remember the thongs that bound his feet; nevertheless the marks they left testified to that doom toward which his feet were leading him. The man does not remember the hand that struck him, the darkness that frightened him ... nevertheless, the hand and the darkness remain with him, indivisible from himself forever, part of the passion that drives him wherever he thinks to take flight. $^{34}$ 
The inescapability of the past is an incessantly repeated refrain in Baldwin's writings, and it is clear that by "the past" Baldwin does not only mean the legacies of chattel slavery, Jim Crow, and the other mechanisms of white supremacy, but also the inescapable idiosyncratic histories of individuals. Despite differences, individuals share a common heritage in what Baldwin calls the "heat, horror and pain of life itself." ${ }^{35}$ Moreover, the inability to countenance this inheritance is inextricably linked to Americans' racial innocence; the unwillingness or incapacity to confront the horrors and terrors of early life-and to wrest from them a coherent self-is part of what feeds our pathological racial politics. As Baldwin said, "you can't deal with anybody who pretends that he doesn't come from where he comes from." 36

\section{The Positions}

Unlike Freud's notion of hard developmental stages, Klein argued that internal life is characterized by an alternation between different "positions." The positions are neither chronological nor inevitably successive; instead, they refer to the ego's oscillation between different forms of experience depending on environmental stresses and internal capacities. Klein describes two primary positions: the "paranoidschizoid" and the "depressive." The positions are an unavoidable inheritance of the earliest months of life, and they coalesce into different cognitive-affective modes of perception - with associated defenses-that recur periodically throughout life. Each position provides a schema that organizes the self, its internal anxieties and fantasies, and its experiences in the world. ${ }^{37}$

The paranoid-schizoid position originates at birth, when the ego is relatively unintegrated and incapable of distinguishing sharply between inner and external worlds. ${ }^{38}$ Initially the infant's inner world is characterized by a bifurcation between "all-good" and "all-bad" figures, reflecting the split experience of early life between experiences of comfort and extreme stress. The early ego bifurcates the world between the all-giving "good breast" and the persecutory "bad breast," which serves as a receptacle for the negative emotions associated with stress and deprivation. ${ }^{39}$ The early ego deploys this defense as both a hedge against an intolerable reality and as a result of cognitive incapacity. Internal discomfort is projected out onto the fantastical "bad" objects, which are then re-internalized to form the kernel of the first superego. The superego in turn rages against the subject with all the frustration, anxiety, and hate that the ego itself could not contain. For Klein, then, early and unavoidable experiences of deprivation and impotency condemn the individual to a pathological state of mind whereby their objects of perception are shaded by the polarized passions of love and hate. The inner world is constructed within this position through a process of what Klein called "projective identification." Projective identification is the process of projecting parts of the self onto an external object. Under the pressures of early anxieties, projection enables the evacuation of intolerable aspects of the self onto external objects, only to re-invade the internal world of the ego as persecutory figures. This paranoid-schizoid position is characterized by feelings of persecutory anxiety and 
by manic defenses that distort perceptions of self and other in order to protect the fragile ego.

Within the depressive position, on the other hand, the ego overcomes these defenses and develops a capacity to integrate the heretofore polarized aspects of its internal and external worlds. ${ }^{40}$ The depressive position is first heralded by the development of object permanency, which marks a cognitive and affective watershed insofar as it permits the discovery that the split objects of early life are merely parts of the same object-the caregiver. In the earlier, paranoid-schizoid position, the internalized attachments are split apart and treated as radically distinct objects. The depressive position, due to the development of object permanency, marks the first appearance of loss - namely, the loss of the idealized, protective "good breast," which up to this point had been invested with all the feelings of warmth, care, and goodness within the child's early life. The good breast is a fantasized object that is discovered to be part of a larger, more complex whole. Recognizing the whole other, then, inspires a "psychical weaning" from the compromises and defenses of the paranoid-schizoid position. ${ }^{41}$

Within the depressive position, the individual develops the capacity to relinquish the image of an ideal or pure object. Conflicts with one's objects and within one's self can be made conscious for the first time. As the ego increases its ability to live with the competing and conflicted demands of its objects and its desires, the individual cultivates a deeper tolerance and generosity toward both self and other. The depressive position in this respect marks a mitigation of cognitive and affective dogmatism, and the overcoming of the compromises and defenses by which the ego keeps the complexity and ambivalence of self and other out of its conscious awareness. Steps in ego integration result "in a greater capacity . . . to acknowledge the increasingly poignant psychic reality." ${ }^{2}$

The depressive position seems to operate for Klein as an aspirational or normative position of ego coherence and maturity, because it is within the depressive position that the individual can make repairs to their internal and external objects that have been damaged through fantasized or actual attacks. Yet despite the development of these capacities, the original, chaotic experiences of the paranoidschizoid position and its corollary defenses are never fully cast aside. Therefore the "maturity" of the depressive position is never complete or permanent, as there are always fluctuations between the two primary positions. The relatively-or the habitually-well-integrated ego nevertheless has clearer insight "into the variety of our contradictory impulses and feelings" along with "the capacity to come to terms with these .. . conflicts." ${ }^{43}$ Moreover, within the depressive position the individual is able to develop a non-manic form of hope rooted in the "pleasures . . . and continuity of life," alongside a capacity for "resignation without undue bitterness." ${ }^{4}$

Many of Baldwin's ideas are put into deeper relief against the background of Klein's concepts and categories. For Klein, the paranoid-schizoid position is characterized above all by defenses against fears of disintegration-feelings of absolute insecurity and instability that, in turn, call forth defenses such as splitting, idealization, and demonization. Baldwin echoes this idea when he writes that what "drives 
people" is "pure terror." 45 This terror has both psychological and historical roots. In the American context, the specific terror that drives people is rooted in the disavowed knowledge of the crimes of white supremacy. "Whites . . know the crimes they have committed against black people. And they are terrified that these crimes will be committed against them." ${ }^{46}$ Americans' peculiar racial history locks them into a kind of paranoid-schizoid functioning, in which the terror of their collective inheritance has to be split off or denied. Baldwin sees this nexus of defenses as the strongest source of support for group identity in the racialized polity. "It is . . . comparatively easy," Baldwin argued, "to invest a population with false morale by giving them a false sense of superiority," and this sense of superiority is predicated upon and held in place by racial inferiors, who serve as a receptacle for the terror that cannot be acknowledged. ${ }^{47}$ Identity cannot be imagined outside of these polarized terms, as evidenced by the fact that "progress" is imagined only in terms of "how quickly a Black kid can become white." ${ }^{8}$ Yet this very process implicitly relies upon the racialized other, who is used to reinforce the basic boundaries of social privilege and recognition.

"Whiteness," then, is akin to a paranoid-schizoid "state of mind." ${ }^{49}$ It is rooted in a terror that cannot be expressed because to do so would cause the disintegration of the constructed boundaries that reinforce identity-and hence would threaten the dissolution of the self. Yet this is a deeper or broader struggle for Baldwin than the particular phenomenon of white supremacy. For Baldwin, ultimately, it is not even a question of race. Race itself is a "cowardly" concept that "has no validity whatever." 50 Race is an "illusion" that is connected, Baldwin implies, to more basic human needs for security and a fight against anxieties of disintegration. The security of racial identity, as it were, is a fantasy of the "good breast"-a reassurance of a social floor below which one cannot fall. The good breast is a hallucination, yet the grip of this hallucination is particularly powerful in a country with the historical inheritance of the United States-a history that includes genocide, displacement, and terror. Once again, the specific historical situation of Americans promotes a kind of collective paranoid-schizoid position, with fantasies of epic heroes and abject others that serve as release valves for unarticulated and inarticulable anxieties.

Nevertheless, for Baldwin as for Klein, the paranoid-schizoid position is a compromised, dangerous, and even self-destructive form of existence. In Baldwin's terms, "nothing worse happens to a man or a woman, a person or a people, than to deny, to lie about, to make a fantasy out of, one of the central facts of their lives. That man, that woman, that person, that people atrophies." ${ }^{11}$ Americans "have not been able to accept the fact that their reality is entangled and almost defined by the black reality." 52 The very categories - or "states of mind" - of white and black in fact ensure that the entanglements and blood-ties in American identity will be denied. Social practices of separation reinforce these categories and prolong the misrecognition of entanglement. All of this, however, comes with a significant cost: "you can't deny your brothers without paying a terrible price for it." ${ }^{33}$

For Baldwin, the innocence of American life is in many ways a product of what Klein called projective identification. Baldwin repeatedly interpreted race 
not only as a certain way of seeing but also as the production of certain sightsnamely, "the nigger" and the associated stereotypes of black life such as "Uncle

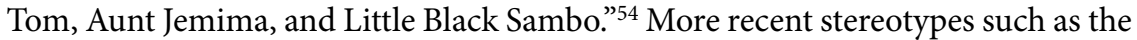
black "supercriminal" or the "welfare queen" serve the same essential purpose-to reinforce dreams of white innocence. ${ }^{55}$ The production of such caricatures is intertwined with an inability to countenance deep human anxieties and the terrors of life. The "nigger" in the mind of the white citizen means that "what they do see when they do look at you is what they have invested you with ... all the agony, and pain, and the danger, and the passion, and the torment-you know, sin, death, and hell-of which everyone in this country is terrified." ${ }^{6}$ Once again, the specific practices of white supremacy were, for Baldwin, inextricably connected to the "heat, horror and pain of human life itself" and to the relatively undeveloped human and social capacity to face down this horror. ${ }^{57}$ Ultimately, Baldwin connects this incapacity and the related need for projection to the struggle against death, or what Klein would see as a paranoid-schizoid anxiety of disintegration:

If you are a Negro dealing with people all day long, all year long, all life long, who never look at you, then you have to figure out one day what they are looking at. Obviously it isn't you ... it wasn't me, it was something he didn't want to see. And you know what that was? It was ultimately, yes, his own death. Or call it trouble. Trouble is an excellent metaphor for death. ${ }^{58}$

Innocence, then, is both a psychological state of mind and a historical inheritance, reinforced by a political and social environment crowded with myths of overcoming, transcendence, and rebirth. America, Baldwin once said, "affords too many opportunities to avoid reality." ${ }^{59}$ Yet the avoidance of reality is not simply a succession of political choices; it is rooted in deep human needs and anxieties, and it trades upon defense strategies that are as much psychological as they are political. "White America," on Baldwin's reading, "refuses to acknowledge the 'horror' as well as the 'beauty' of its history." ${ }^{\prime \prime 0}$ Once again, although this refusal is most acute when it comes to the question of race, Baldwin argues that "danger, terror, [and] anguish" issuing from practices of white supremacy must be "connect[ed] to the human condition ... and not divorce[d] from it ... [and] race has absolutely nothing to do with it." ${ }^{61}$ Baldwin, of course, does not deny that race has fundamentally shaped social experiences. Race is an illusion, but it is an illusion that has had significant political and social effects: "color is a fact . . it is a fact of my life because I had to live a certain life because I am black. It is a fact of your life, because you see me in a certain way, because I am black." 62 Despite his use of "see," we may take Baldwin to mean that race is less a way of seeing and more a kind of blindness that reinforces innocence. He presses his audience to admit this blindness along with its causes and consequences, which requires entry into a kind of social depressive position.

For Klein, the depressive position involves an acceptance of tragedy rooted in the acknowledgment of the ambivalence of self and other-the lack of all-good 
angels or all-bad demons. Initially, the depressive position involves the dawning awareness of the "whole" object. This watershed in individual development can also be seen as the kernel of the work of social acknowledgment that Baldwin repeatedly invokes. For Baldwin, the American experiment, despite its horrors, is not a one-sided catastrophe but an ambivalent object containing both love and murder. As Baldwin once reflected, "we've had to go through many dangerous toils and snares . . . but there is more than that behind us. If not, we wouldn't be able to walk a single day or draw a breath." ${ }^{3}$ For Baldwin, the challenge is to let neither the necessary remembrance of "toils and snares" obscure the resiliency and agency of the "more than that," nor to let stories of survival and resiliency serve as a means of denying the ongoing catastrophe. The struggle, rather, as Baldwin wrote in Notes of a Native Son, is both to accept "totally without rancor . . . life as it is, and men as they are" while also refusing to "accept ... injustices as commonplace" and to "fight them with all one's strength." ${ }^{4}$ When asked in an interview to reconcile these two attitudes, Baldwin - in Kleinian fashion-refused to do so: "I don't think you do [reconcile them] ... you accept life as it is, you see it as it is before you can change it." 65

For Baldwin, seeing "life as it is" obviously involves an awareness of the socially structuring and saturating effects of white supremacy; his primary referent for the "heat, horror, and pain" of life is therefore the experience of black life in America. Baldwin's depressive awareness then, manifests itself primarily as a bitter knowledge of a violent history and present-a "complex history" of a "complex country ... that insists on being simpleminded." ${ }^{6}$ As Baldwin puts it, "I know where I've been. I know what the world has tried to do to me as a black man ... I know that it's not easy to live in a world that's determined to murder you ... the secret of the white world is out. Everybody knows it." ${ }^{67}$ Yet Baldwin rarely fails to connect this labor of historical and social acknowledgment to a broader human struggle: "the human fact is this: that one cannot escape anything one has done. One has got to pay for it." ${ }^{\prime 8}$ The tragic acknowledgment of the generic difficulty of life-its terrors and its loneliness, its bitterness and frailty-is inextricably connected for Baldwin to the struggle against racial injustice, and vice versa. The attack against white supremacy, therefore, involves a revolution that necessarily "begins first of all in the most private chamber of somebody's heart, in your consciousness." ${ }^{\prime} 9$

In its essence, we can call this a politics of the depressive position. Any change "in the state" requires an "absolutely unthinkable revision of the American identity," which begins with the depressive acknowledgment that "all of us are much more devious and mysterious than we think we are." ${ }^{\prime 0}$ It is only by accepting "life as it is" that we can challenge misleading myths of progress and obtain a certain level of what Baldwin called "maturity."71 In a Jeremiadic performance at the Washington Press Club in 1986, Baldwin excoriated his countrymen and women for their refusal of maturity, which feeds pernicious fantasies of racial progress: "When quote/unquote 'white people' talk about progress . . . the only thing they can mean is how quickly and how thoroughly I become white. I don't want to become white; I want to grow up. And so should you." ${ }^{72}$ American innocence is a 
refusal to grow up - a refusal to acknowledge "that the world is big and complex and dark and that you have to grow up and become yourself big and complex and dark in order to deal with it."73 The only viable response to the immaturity and blindness of innocence is a process of psychological transformation, akin to going through the crucible of the depressive position. The result is an earned capacity for accepting tragedy-or what Klein called resignation-that pointedly stops short of despair. Despair goes too far because it forsakes the possibilities of life including love, understanding, and-even-redemption. Baldwin, up to the very end of his life, refused the temptations of despair. As he put it in a 1979 interview, "I am far from being in despair. We cannot afford despair. We have too many children. Despair is a luxury only white men can afford." 74

\section{Integration}

Klein referred to "integration" as the "ultimate aim" of psychoanalysis. ${ }^{75}$ Integration is a "process of synthesis" by which the contrasting aspects of the individual and their experiences become increasingly linked with one another. As Klein puts it, "as the depressive position comes to the fore ... the various aspects-loved and hated, good and bad-of the objects come closer together, and these objects are now whole persons." 76 Integration proceeds through the progressive appropriation of conscious and unconscious destructive impulses under the influence of what Klein called the "good object," which is distinct from the idealized "good breast" because it is a whole, ambivalent object. Integration implies a "measure of synthesis between love and hatred" or the "mitigation of hate by love" in ways that "render ... destructive impulses less powerful."77 The insight gained from integration means that "potentially dangerous parts [of ourselves] ... become bearable and diminish," which permits an "enrichment and deepening of the ego."78

Integration implies, as Klein's successor Hanna Segal argues-in words very reminiscent of Baldwin-seeing "life as it is"-recognizing and overcoming the fantasies and defenses that relieve persecutory anxiety at the cost of denying the complexity of self and other. ${ }^{79}$ According to Segal, Klein's idea of integration marks a transformation of Freud's reality principle into what Segal called a "reality sense," which "means being in a state of mind where you know yourself and don't project, so that you can assess reality and know what can be achieved and what can't." ${ }^{\prime 0}$ The price of integration is the overcoming of the pleasure principle, which is, according to Segal, "the principle of omnipotence imbued with a terrible hatred of reality." The withdrawal of omnipotent projections-issuing from the same terrain of persecutory anxiety-forces individuals "to face their own destructiveness, their inner conflicts and guilt, their internal realities." ${ }^{2}$ It forces individuals to face, in Baldwin's language, the "disquieting complexity" of self and other, and to avoid reducing this complexity in the name of a simpler calculus of friend and enemy, good and bad, that reassures temporarily but poisons in the long run. ${ }^{83}$

Integration, as both Klein and Segal interpret it, comes at a significant cost and is therefore difficult to accept. ${ }^{84}$ Integration proceeds slowly, "step by step," and it is 
"liable to be disturbed under internal and external pressure." 85 As a result, "full and permanent integration is never possible ... complete understanding and acceptance of one's own emotions, phantasies and anxieties is not possible." ${ }^{86}$ Integration is better understood as a continual process or labor rather than an end-state-a task, moreover, that we are not always capable of taking on. Once again, failed integration occurs when we project the discomforting parts of the self out into a persecutory other, and when we construct boundaries to police the fantasized separation.

It is important to emphasize again that Baldwin had something very different in mind when he wrote about integration. For Baldwin, integration in the context of the mid-century "slave rebellion" of the Civil Rights movement was primarily a social and political response to policies and practices of racial segregation. ${ }^{87}$ Nevertheless, throughout his writings Baldwin also discusses integration as a moral or psychological labor that clearly involves the attainment of what Segal called a "reality sense." As he wrote in The Fire Next Time, "if the word integration means anything, this is what it means: that we, with love, shall force our brothers to see themselves as they are, to cease fleeing from reality and begin to change it." 88 Relatedly, separatism-both as a practice of white supremacy and as a strategy of black resistance-was problematic for Baldwin in part because it denied the reality of social entanglement: "separatism is a dream ... I'm related to the white American by blood . . . we cannot separate . . you can't deny your brothers without paying a terrible price for it." 89 Due to Americans' "terrible depth of involvement" with each other, fantasies of separation-and the paranoid-schizoid defenses that accompany such fantasies-are politically and psychologically perilous: "it is hazardous, psychologically, personally hazardous ... for a Negro ... really to hate white people. He is too involved with them." 90 To acknowledge social entanglement requires, however, the obtaining of a social depressive position, rooted in the authentically difficult work of overcoming paranoid-schizoid defenses of omnipotence, denial, idealization, and demonization.

The explicit language of racial integration faded partially from Baldwin's writings and interviews as the deaths of civil rights leaders mounted and as Baldwin's pessimism about his country's collective moral capacity increased. However, a moral and psychological concept of integration remained implicit within his thinking, as did the connection between this idea and the tenability of American democracy. If the American public could not imagine integration in terms other than assimilation- "how quickly and how thoroughly I become white" - then Baldwin steadfastly rejected the terms of this bargain. Yet Klein's idea of integration as the habitual attainment of a sense of reality, the overcoming of omnipotence and the mature acceptance of ambivalence within self and other, still rings clearly in Baldwin-even in the last, increasingly pessimistic, years of his life. Because his focus was always both on personal struggles for coherence and social struggles for justice and community, Baldwin's work brings Klein's conceptual terminology out of the intimate and analytic spaces to which it is often restricted, and reveals the urgent politics of the depressive position. 
For Baldwin, the attainment of identity involves the disruption and overcoming of a certain picture of the world-a world constructed by defenses both against the inescapable anxieties of life and the terrifying historical inheritance of the American polity. In depressive awareness of these defenses, we might see the "safety" they offer as both misleading and pathological-personally and politically. Yet Baldwin may have overlooked the conditions necessary for this awareness. The availability of the depressive position depends upon an environment and objects of what Wilfred Bion called "containment." Extending Klein's approach into the realm of group functioning, Bion noted how the tenability of the depressive position depends upon the existence of a receptive environment in which groups hold and transform the destructive tensions and anxieties within and between subjects. In a well-functioning group-what Bion calls a "work group"-these destructive or aggressive anxieties and projections can be contained and modified. ${ }^{91}$ Work groups can register and experience frustration, and innovate new vocabularies to deal with these frustrations.

However, for Bion, while the environment surrounding the individual can actively contain and transform paranoid-schizoid madness, just as often it feeds or magnifies this madness. Group identification more often than not rests on psychotic premises of omnipotence or on foundations of unarticulated or uncontained anxiety, which manifest as claims of inherent superiority or as hostility toward out-groups. In most groups, not only is there little interest in challenging these premises, but in fact the very hint of their erosion would provoke the type of crisis that the group exists to prevent. While Baldwin and Klein each call on individuals to see "life as it is," groups exist, psychologically speaking, to ward off this work of reality acceptance.

Baldwin's repeated excoriations of American identity—and of "whiteness" - can be usefully approached from within the terms of Bion's theories of group functioning. America, once again, "affords too many opportunities to avoid reality."92 American society provides an "illusion of safety" and as a result Americans "lack a sense of tragedy." ${ }^{\prime 93}$ For Baldwin, the avoidance of tragic reality is reinforced by the lionization of a particular type of political leader. In the figure of Ronald Reagan, for instance, Baldwin saw evidence for his belief that Americans valued the sincerity of adolescence over the depth of maturity, and that they preferred simplicity over complexity. As Baldwin argued, "the effect on the American people of the presence of such men in high office is that they are justified in their bigotry, they are confirmed in their ignorance, they are all smaller or great John Waynes." ${ }^{\prime 4}$

Baldwin shows the need, then-borrowing the language of object relations psychoanalysis-for "whole" objects that reflect ambivalence, and for cultural practices and spaces of "containment." For Klein, the good object, as distinguished from the ideal object, contains both love and hate and enables the integration of polarized experiences and emotions. As the need for idealization diminishes, the capacity for integration increases, heralding a more coherent self. For both 
Baldwin and Klein, this process of integration is what makes love, trust, and agency possible.

What, however, are the objects that can actually "hold us together" such that we might pursue the social "maturity" of integration heralded by Baldwin? What are the objects that permit us to know ourselves and to know the conflicts within and between self and others? In searching for an answer to these questions, Baldwin seemed to rely on "poets" such as Billie Holiday or Bessie Smith. Poets offer a disagreeable mirror that refines and gives back experience; they make experience bearable in part by offering new ways in which individuals can understand themselves. Baldwin clearly saw himself in this role. In his own words, the writer does not merely attempt to communicate to the world "how I've suffered, because who cares ... it's an act of 'I love you." ${ }^{95}$ Baldwin's prophetic speech spanning four decades, from warnings in the early 1960s about "the fire next time" to the those in 1985 about the impending "apocalypse" of Western civilization, were loving attempts to hold and reflect the ambivalence and complexity of a brutal, brokenand yet oftentimes beautiful and possibly redemptive-historical inheritance and social reality. ${ }^{96}$

Better objects, however, are not enough; "poets" are not sufficient. This is so in part because basic group formations are an easier outlet for persecutory anxieties and because such groups have little need for, or interest in, such complex, whole objects. As Segal argues, the "group chooses its leader according to its orientation." ${ }^{\prime 7}$ In other words, groups often select objects that will reinforce their pathological defenses, not objects that will call those defenses into question. Groups do not often contain anxieties but magnify and focus them through scapegoats and stereotypes. The limitation of the poet or the analyst, therefore, is that while they may indicate blockages in particular vocabularies, they cannot create a new vocabulary by themselves. Only groups can create a vocabulary. Baldwin, especially in his last few years, repeatedly emphasized that the "political vocabulary" of his age was bankrupt or broken. The public narrative or vocabulary of the Western world "cannot serve the needs of this age." 98 The "only hope" was that "Western hegemony and civilization" could be "contained." 99 The challenge, for Baldwin, was to change or to "invest the vocabulary with something it doesn't contain yet ... I'm trying to find another word besides Negro to say what I mean and I can't use tragedy . . . because I haven't figured out the terms on which I can use it yet."100

Unfortunately, Baldwin could not seem to imagine viable spaces and practices of containment-through which new vocabularies could be tested out and put into circulation-even though he seemed to intuit the desperate need for those spaces. Almost three decades after his death, can we say that settings or "work groups" for containment and acknowledgment are more apparent or possible? There are some encouraging developments in this direction. For instance, recent efforts to create "truth and reconciliation" processes in localities touched by historical traumas of misrecognition are a compelling development. ${ }^{101}$ Such processes reveal a social commitment-however nascent, precarious, or marginal - to include shameful and difficult events within public narratives and to create public dialogue around 
the legacies of these events. ${ }^{102}$ Truth and reconciliation processes do not represent an extension of psychoanalytic technique so much as they can draw energy from psychoanalytic insight about, as Segal puts it, the need to "face ... the reality of history" even as doing so "exposes us to what is most unbearable." 103 Although these processes can be influenced by manic pressures or omnipotent fantasies, they also offer an opportunity to establish a reflexive civic practice surrounding traumatic events in ways that allow individuals to face down the ambivalence of their political heritage. ${ }^{104}$

Integration in the context of ongoing racial violence requires a variety of mechanisms through which citizens can engage one another and the living legacies of historical segregation. In this light, truth and reconciliation processes seem like promising social innovations. Drawing on both Klein and Baldwin, we can understand the operations of these processes in terms of "containment." Converting inchoate social anxieties into public narratives and vocabularies provides an orientation for work groups aimed at social justice. Clearly, this invitation to the work of acknowledgment can be spurned, as individuals slide toward basic assumptions and schizoid defenses. Nevertheless, the invitation itself is powerful, important, and worthy of proliferation; it is the basis for a broader culture of containment that might help to develop human capacities for understanding and reparation. ${ }^{105}$

Moreover, as shown by the recent operation of local truth and reconciliation commissions, these processes can also have important after-effects. In the wake of the Greensboro Truth and Reconciliation Commission (2004-06) in Greensboro, North Carolina, for instance, several organizations and associations were created, focusing on local issues ranging from a living wage, to police discrimination, to violence prevention. ${ }^{106}$ In other words, truth and reconciliation processes can develop a society's "reality sense," but they also can provide space for the creation of concrete civic efforts aimed at social repair. With the decline of labor unions and other, cross-sectional associations of democratic life, the best hope for social justice movements might be settings similar to truth and reconciliation processes. Yet these spaces could be more effective if they were enlivened by the insights of Klein and Baldwin. Across the differences in their contexts, orientations, and vocations, Baldwin and Klein form a dissonant chorus that can illuminate the difficulties and depths of the politics of integration, while simultaneously underlining its possibilities and its urgency.

\section{Notes}

1 James Baldwin, The Fire Next Time (London, Vintage, 1992), pp.9-10. Emphasis in original.

2 Michelle Alexander, The New Jim Crow (New York, The New Press, 2010).

3 Glenn Loury, "Why Are So Many Americans in Prison?, Boston Review, 1 July 2007, p. 1.

4 Beverly Gage, "What an Uncensored Letter to M.L.K Reveals," The New York Times, 11 November 2014, MM15. 
5 Michael S. Schmidt, "F.B.I. Director Speaks Frankly About Police View of Blacks," The New York Times, 12 February 2014, A1.

6 James Baldwin, "Many Thousands Gone," in The Price of the Ticket: Collected Nonfiction 1948-1985 (New York, St. Martin's Press, 1985), p. 76.

7 Baldwin, The Fire Next Time, p. 10.

8 Throughout this article, I focus mainly on Baldwin's many interviews rather than on his novels or nonfiction essays. The conversational and interactive nature of the interview format most closely resembles the dialogical engagement of the psychoanalytic encounter. Nancy Luxon refers to such encounters in terms of a "combative collaboration" in which the agency of the listener/speaker can be cultivated. Baldwin's interviews and public engagements, then, were the way in which he offered and practiced a kind of combative collaboration with his audience. Nancy Luxon, Crisis of Authority: Politics, Trust, and Truth-Telling in Freud and Foucault (New York, Cambridge University Press, 2013), p. 52.

9 "Interview with the Paris Review," in Fred L. Standley and Louis H. Pratt (eds.), Conversations with James Baldwin (Jackson, MS, University of Mississippi Press, 1989), p. 247.

10 James Baldwin, Tell Me How Long the Train's Been Gone (London, Vintage, 1998), p. 421.

11 Baldwin, "Many Thousands Gone," p. 68.

12 "Interview with John Hall," in Standley and Pratt (eds.), Conversations with James Baldwin, p. 98.

13 George Shulman, American Prophecy: Race and Redemption in American Political Culture (Minneapolis, MN, University of Minnesota Press, 2008), p. 140.

14 "Interview with Studs Terkel," in Standley and Pratt (eds.), Conversations with James Baldwin, p. 14.

15 "Interview with Malcolm Presten," in Standley and Pratt (eds.), Conversations with James Baldwin, p. 26.

16 Baldwin, "Many Thousands Gone," p. 76.

17 Lauren Rusk, "Selfhood and Strategy in Notes of Native Son," in D. A. McBridge (ed.), James Baldwin Now (New York, NYU Press, 1999), p. 371.

18 Ibid.

19 "The Black Scholar Interviews James Baldwin," in Standley and Pratt (eds.), Conversations with James Baldwin, p. 155.

20 Shulman, American Prophecy, p. 137.

$21 \mathrm{Ibid}$.

22 In this respect, I deploy psychoanalysis in the spirit of figures such as Michael Rogin. See Michael Rogin, Ronald Reagan the Movie: And Other Episodes in Political Demonology (Berkeley, CA, University of California Press, 1987). See also George Shulman, "Michael Rogin (1937-2001)," Political Theory, 30:3 (2002), pp.316-19.

23 Melanie Klein, "The Origins of Transference," in Envy and Gratitude and Other Works 1946-1963 (New York, Free Press, 1975), p. 53.

24 Robert Meister, After Evil: A Politics of Human Rights (New York, Columbia University Press, 2011), p. 35.

25 See Jay Greenberg and Stephan A. Mitchel, Object Relations in Psychoanalytic Theory (Cambridge, MA, Harvard University Press, 1983).

26 Baldwin, "Many Thousands Gone," p. 28. 
27 Melanie Klein, "Notes on Some Schizoid Mechanisms," in Envy and Gratitude and Other Works, pp. 8-11.

28 Melanie Klein, "Envy and Gratitude," in Envy and Gratitude and Other Works, p. 231.

29 James Baldwin, "The Crusade of Indignation," in The Price of the Ticket, p. 159.

30 Sigmund Freud, Civilization and its Discontents (New York, W.W. Norton, 1989); Melanie Klein, "Some Theoretical Conclusions Regarding the Emotional Life of the Infant," in Envy and Gratitude and Other Works, pp. 61-93.

31 Freud, Civilization and its Discontents, p. 82.

32 "Interview with Studs Terkel," p.8.

33 "Interview with Eve Auchincloss and Nancy Lynch," in Standley and Pratt (eds.), Conversations with James Baldwin, p. 66.

34 Baldwin, "Many Thousands Gone," p. 68.

35 Ibid., p. 78.

36 "Interview with Eve Auchincloss and Nancy Lynch," p. 71.

37 Thomas Ogden, Matrix of the Mind (London, Jason Aronson, 1993), p. 4.

38 Klein, "Notes on Some Schizoid Mechanisms," p. 4.

39 Melanie Klein, "On the Theory of Anxiety and Guilt," in Envy and Gratitude and Other Works, pp. 31-4.

40 The term "depressive" can be misleading. Depressive capability must be distinguished from outright depression or melancholia, which are typified by an absence of affect, withdrawal from the world, and a disregard for the self. By contrast, the person capable of being depressed can sustain the stresses and strains within internal and external realities, and this ability serves as a hedge against depression or a debilitating melancholia.

41 Meira Likierman, Melanie Klein: Her Work in Context (London, Continuum, 2001).

42 Ibid., p. 74.

43 Klein, "On Mental Health," in Envy and Gratitude and Other Works, p. 269.

44 Klein, "Envy and Gratitude," p. 203.

45 "Interview with Studs Terkel," p.8.

46 Ibid.

47 "Interview with Kenneth Clark," in Standley and Pratt (eds.), Conversations with James Baldwin, p. 44.

48 Ibid., p. 183.

49 “Interview with Kalamu ya Salaam," (1979) in Standley and Pratt (eds.), Conversations with James Baldwin, p. 179.

50 "Interview with Wolfgang Binder," in Standley and Pratt (eds.), Conversations with James Baldwin, p. 200.

51 "James Baldwin finds New South is a Myth," in Standley and Pratt (eds.), Conversations with James Baldwin, p. 188.

52 "Interview with Wolfgang Binder," p. 208.

53 "Interview with John Hall," p. 108.

54 "Interview with Kalamu ya Salaam," p. 180.

55 Ange Marie Hancock, The Politics of Disgust (New York, NYU Press, 2004), p. 3.

56 "Interview with Studs Terkel," p.6.

57 Baldwin, "Many Thousands Gone," p. 78.

58 "Interview with Eve Auchincloss and Nancy Lynch," p.73.

59 "Interview with Julius Lester" (1984), in Standley and Pratt (eds.), Conversations with James Baldwin, p. 230. 
60 "The Black Scholar," in Standley and Pratt (eds.), Conversations with James Baldwin, p. 157.

61 "Interview with Wolfgang Binder," p. 200.

62 "Encounter," in Standley and Pratt (eds.), Conversations with James Baldwin, p. 117.

63 "Interview with Jewell Handy Gresham," in Standley and Pratt (eds.), Conversations with James Baldwin, p. 160.

64 "Interview with John Hall," p. 105.

65 Ibid.

66 James Baldwin, “Speech at Washington DC Press Club," 10 December 1986, https:// www.youtube.com/watch?v=CTjY4rZFY5c (accessed 8 September 2016).

67 "Interview with Ida Lewis," in Standley and Pratt (eds.), Conversations with James Baldwin, p. 91.

68 "Interview with Studs Terkel," p. 12.

69 “The Black Scholar," p. 157.

70 "Interview with Kalamu ya Salaam," p. 180; "Interview with Jewell Handy Gresham," p. 165.

71 James Baldwin, "Notes on the House of Bondage," in The Price of the Ticket, p. 673.

72 Baldwin, "Speech at Washington at DC Press Club."

73 "Interview with James Mossman," in Standley and Pratt (eds.), Conversations with James Baldwin, p. 57.

74 "Interview with Kalamu ya Salaam," p. 182.

75 Klein, "Envy and Gratitude," p. 231.

76 Klein, "Some Theoretical Conclusions Regarding the Emotional Life of the Infant," p. 73.

77 Melanie Klein, "On the Sense of Loneliness," in Envy and Gratitude and Other Works, p. 301.

78 Klein, “Envy and Gratitude," p. 189.

79 Hanna Segal, Yesterday, Today, and Tomorrow (London, Routledge, 2007), p. 51.

80 Ibid., p. 251.

81 Ibid., p. 60.

82 Ibid., p. 41.

83 James Baldwin, "Everybody's Protest Novel," in The Price of the Ticket, p. 29.

84 Klein "On the Sense of Loneliness," p. 301.

85 Ibid.

86 Ibid., p. 302.

87 "Interview with Wolfgang Binder," p. 194.

88 Baldwin, The Fire Next Time, p. 10. Emphasis added.

89 "Interview with John Hall," p. 100.

90 "Interview with Studs Terkel," p.7.

91 Wilfred Bion, Experiences in Groups (London, Routledge, 1991), p. 7.

92 "Interview with Julius Lester," p. 230.

93 "Interview with Studs Terkel," p. 22.

94 "Interview with John Hall," p. 99.

95 "Interview with Jewell Handy Gresham," p. 162.

96 Baldwin, The Fire Next Time; "Interview with Henry Louis Gates," in Standley and Pratt (eds.), Conversations with James Baldwin, p. 269.

97 Segal, Yesterday, Today, and Tomorrow, p. 163. 
98 "Interview with Mavis Nicholson," 5 April 1986, https://www.youtube.com/ watch?v=3Wht4NSf7E4 (accessed 8 September 2016).

99 "Interview with Quincy Troupe," in Standley and Pratt (eds.), Conversations with James Baldwin, p. 292.

100 “Interview with Eve Auchincloss and Nancy Lynch," p. 81.

101 See Fania E. Davis, "Truth and Reconciliation is Coming to America from the Grassroots," The Guardian, 26 February 2015, http://www.theguardian.com/commentisfree/2015/ feb/26/truth-and-reconciliation-is-coming-to-america (accessed 1 March 2015).

102 Lisa Magarrell and Joya Wesley, Learning from Greensboro: Truth and Reconciliation in the United States (Philadelphia, PA, University of Pennsylvania Press, 2008), pp. $7-10$.

103 Hanna Segal, "From Hiroshima to the Gulf War and After: Socio-political Expressions of Ambivalence," in Psychoanalysis, Literature and War (London, Routledge, 1995), p. 167.

104 This argument is developed in David W. McIvor, Mourning in America: Race and the Politics of Loss (Ithaca, N.Y., Cornell University Press, 2016), pp. 157-70.

105 C. Fred Alford, Trauma and Forgiveness (Cambridge, Cambridge University Press, 2014), pp.3-5.

106 Spoma Jovanovic, Democracy, Dialogue, and Community Action (Fayetteville, AR, University of Arkansas Press, 2012), pp. 8-10.

\section{Works Cited}

Alexander, Michelle, The New Jim Crow (New York, The New Press, 2010).

Alford, C. Fred, Trauma and Forgiveness (Cambridge, Cambridge University Press, 2014).

Baldwin, James, The Fire Next Time (London, Vintage, 1992).

The Price of the Ticket: Collected Nonfiction 1948-1985 (New York, St. Martin's Press, 1985).

_ "Speech at Washington DC Press Club," 10 December 1986, https://www.youtube. com/watch?v=CTjY4rZFY5c (accessed 8 September 2016).

- Tell Me How Long the Train's Been Gone (London, Vintage, 1998).

Bion, Wilfred, Experiences in Groups (London, Routledge, 1991).

Davis, Fania E., "Truth and Reconciliation is Coming to America from the Grassroots," The

Guardian, 26 February 2015, http://www.theguardian.com/commentisfree/2015/feb/26/

truth-and-reconciliation-is-coming-to-america (accessed 1 March 2015).

Freud, Sigmund, Civilization and its Discontents (New York, W.W. Norton, 1989).

Gage, Beverly, "What an Uncensored Letter to M.L.K Reveals," The New York Times, 11 November 2014.

Greenberg, Jay, and Stephan A. Mitchel, Object Relations in Psychoanalytic Theory (Cambridge, MA, Harvard University Press, 1983).

Hancock, Ange Marie, The Politics of Disgust (New York, NYU Press, 2004).

Jovanovic, Spoma, Democracy, Dialogue, and Community Action (Fayetteville, AR, University of Arkansas Press, 2012).

Klein, Melanie, Envy and Gratitude and Other Works 1946-1963 (New York, Free Press, 1975).

Likierman, Meira, Melanie Klein: Her Work in Context (London, Continuum, 2001).

Loury, Glenn, “Why Are So Many Americans in Prison?” Boston Review, 1 July 2007. 
Luxon, Nancy, Crisis of Authority: Politics, Trust, and Truth-Telling in Freud and Foucault (New York, Cambridge University Press, 2013).

Magarrell, Lisa, and Joya Wesley, Learning from Greensboro: Truth and Reconciliation in the United States (Philadelphia, PA, University of Pennsylvania Press, 2008).

McIvor, David W., Mourning in America: Race and the Politics of Loss (Ithaca, N.Y., Cornell University Press, 2016).

Meister, Robert, After Evil: A Politics of Human Rights (New York, Columbia University Press, 2011).

Ogden, Thomas, Matrix of the Mind (London, Jason Aronson, 1993).

Rogin, Michael, Ronald Reagan the Movie: And Other Episodes in Political Demonology (Berkeley, CA, University of California Press, 1987).

Rusk, Lauren, "Selfhood and Strategy in Notes of Native Son," in D. A. McBridge (ed.), James Baldwin Now (New York, NYU Press, 1999), pp. 360-92.

Schmidt, Michael S., "F.B.I. Director Speaks Frankly About Police View of Blacks," The New York Times, 12 February 2014.

Segal, Hanna, "From Hiroshima to the Gulf War and After: Socio-political Expressions of Ambivalence," in Psychoanalysis, Literature and War (London, Routledge, 1995). Yesterday, Today, and Tomorrow (London, Routledge, 2007).

Shulman, George, American Prophecy: Race and Redemption in American Political Culture (Minneapolis, MN, University of Minnesota Press, 2008). "Michael Rogin (1937-2001)," Political Theory, 30:3 (2002), pp.316-19.

Standley, Fred L., and Louis H. Pratt (eds.), Conversations with James Baldwin (Jackson, MS, University of Mississippi Press, 1989).

\section{Contributor's Biography}

David W. McIvor received his B.A. in Political Science at Western Washington University and his M.A. and Ph.D. in Political Science from Duke University. His primary research interests are in contemporary political theory and democratic theory with a particular focus on critical theory psychoanalytic theory and deliberative democratic theory and practice. He has published articles in a variety of scholarly journals including Political Theory, Constellations, Polity, and Contemporary Political Theory. He was also a co-editor of Democratizing Deliberation: A Political Theory Anthology published by the Kettering Foundation in 2012. His first book, entitled Mourning in America: Race and the Politics of Loss, is forthcoming from Cornell University Press. He teaches courses in political theory at both the graduate and undergraduate level. 